\title{
Spotkanie homiletów Arbeitsgemeinschaft für Homiletik (Monachium, 27-30 września 2010)
}

W dniach od 27 do 30 września 2010 roku odbyło się w Monachium spotkanie homiletów należących do międzynarodowego stowarzyszenia Arbeitsgemeinschaft für Homiletik. Miejscem obrad była urocza i pięknie położona rezydencja Schloss Fürstenried służąca za ośrodek rekolekcyjny i konferencyjny archidiecezji Monachium-Fryzynga (Exerzitienhaus der Erzdiözese München und Freising), w którym przed laty przebywał w czasie studiów teologicznych Józef Ratzinger. Swoje wspomnienia z semestru 1947/1948 opisał w książce Aus meinem Leben. Erinnerungen (1927-1977), Stuttgart 1998, s. 52, 67. Tematem spotkania było Kazanie i grzech (Predigt und Sünde). Wprowadzenia w temat konferencji naukowej dokonał ewangelicki biskup Gerhard Ulrich, a po nim prof. Erich Garhammer z Würzburga. Zwrócili oni uwagę na aktualność zagadnienia grzechu rozpatrywanego w wymiarze ekumenicznym: katolickim i ewangelickim. Nawiązali do dramatycznych wydarzeń dotyczących molestowania nieletnich. Zaznaczyli jednocześnie, że mówienie o grzechu zakłada też mówienie o przebaczeniu.

Wykład wprowadzający do konferencji wygłosił prof. dr Michael Meyer-Blanck. Dotyczył on historycznej i protestanckiej perspektywy podjętego zagadnienia i był połączony z prezentacją przykładów kazań na temat grzechu. Mówca zauważył, że przy omawianiu grzechu nie chodzi tylko o błędy poszczególnych osób, ale o cały wymiar ludzkiej egzystencji naznaczonej grzechem. Przypomniał żart o tym, że każde kazanie o grzechu można streścić w ten sposób, że kaznodzieja był przeciw. Prof. Meyer-Blanck podkreślał, że mówienie o grzechu domaga się uzupełnienia o stwierdzenie, że Jezus przezwyciężył grzech. Analizując, dlaczego ten rodzaj kaznodziejstwa jest niepopularny, prelegent wskazał na takie błędy, jak mówienie ogólne, a nie konkretne, czyli przeobrażenie kazania o grzechu i sprawiedliwości w wykład, a także moralizowanie, czyli wskazywanie, co czynić, by podobać się Bogu. Następnie mówca zauważył, że według ewangelicznych opisów Jezus na początku nie pytał, czy człowiek jest grzesznikiem, czy też nie, ale nawiązywał z nim relację, mówił do każdego człowieka. Dopiero potem rodziło się w człowieku doświadczenie, które wyraził Piotr: „Odejdź ode mnie, Panie, bo jestem człowiek grzeszny” (Łk 5, 8). Jezus dotarł do Piotra. Dziś dostrzega się rozpowszechniony brak bojaźni Bożej i czci Boga. Można mówić o schorowanym sumieniu współczesnego człowieka. Zamiast o grzechu mówi się o poczuciu winy bez odniesienia do Boga. Ponadto prof. Meyer-Blanck zwrócił uwagę na współczesne wyzwania wobec kazań o grzechu: różnica płci a doświadczenie grzechu (kobiety szybciej niż mężczyźni doświadczają poczucia winy); poczucie grzechu a poczucie winy (w psychologii pastoralnej rozróżnia się winę i poczucie winy - istnieje poczucie winy bez samej winy, kazanie powinno to uwzględniać); doświadczalny wymiar grzechu i łaski. Wskazując na konsekwencje współczesnej refleksji teologicznej nad grzechem dla homiletyki, prelegent stwierdził, że w kazaniu należy unikać moralizowania i trywializowania; pytanie 
o moralność nie powinno być oddzielone od pytania o Boga, czyli moralność musi być odnoszona do Boga, a pytanie o Boga musi obejmować pytania moralne; im bardziej Bóg jest ujmowany personalnie, osobowo, tym bardziej moralność jest ujmowana jako doświadczenie Boga, a mówienie o tym uwzględnia doświadczenie kaznodziei, które jest bliskie doświadczeniu innych. Błędem natomiast jest akademizacja, czyli mówienie o grzechu bez odniesienia do możliwości uzyskania odpuszczenia grzechów. Kazanie bowiem powinno umożliwić podjęcie ostatecznej decyzji i doświadczenie przebaczenia. Jeśli kazanie pominie rzeczywistość grzechu, będzie mową bez mocy - kazanie o grzechu wskazuje na potrzebę Chrystusa Odkupiciela. Z tej perspektywy „grzech” jest nie tylko ważnym, ale też dobrym tematem kaznodziejskim.

Próby systematyczno-teologicznego spojrzenia na grzech z perspektywy katolickiej dokonał młody teolog dr Jürgen Bründl. Omówił on koncepcje teologiczne dotyczące rozumienia ludzkiej gotowości do odkupienia. Prezentował myśli Rahnera, Schoonenberga i Sievernicha. Zastanawiał się m.in. nad kontrowersyjną kwestią możliwości mówienia o grzechu bez odniesienia do Boga. Podczas późniejszej sesji dr Bründl zaprezentował misteryjny i symboliczny film The serious Man o naukowcu, fizyku kwantowym żydowskiego pochodzenia, który chciał być dobrym człowiekiem, a wciąż doświadczał życiowych przeciwności. Spadały one na niego nieoczekiwanie. Dyskusja po filmie pozwoliła odkryć wiele analogii z biblijną historią zbawienia.

Z kolei o grzechu z perspektywy ewangelickiej mówił w metodycznie uporządkowanym wystąpieniu prof. dr Martin Laube z Bonn. Stwierdził, że mówienie o grzechu wcale nie musi być niezrozumiałe dla współczesnego człowieka. Już na początku zaznaczył, że uznanie grzechu jest wynikiem wiary. Nie pochodzi ono z rozumu, ale ze słowa Bożego. Odwołując się do autorytetu K. Bartha, prelegent stwierdził, że poznanie grzechu wynika ze spotkania z Chrystusem, spojrzenia na Niego. Poznanie grzechu to nie poznanie siebie, ale odbite w zwierciadle poznanie Chrystusa. Nauczanie o grzechu jest cieniem nauczania o łasce. Centrum nauczania ewangelicznego jest nauczanie o łasce Bożej. Grzech i łaska są korelatami, ale czy można kłaść jednakowy nacisk na grzech i łaskę? Według Karla Bartha grzech wszedł na świat wbrew woli Bożej, o czym wyraźnie pisze Paweł Apostoł w Liście do Rzymian. W świecie upragnionym przez Boga nie ma miejsca na grzech. Karl Barth poszedł tu swoją drogą, ponieważ Luter, do którego wraca współczesne nauczanie ewangelickie, mocno eksponował znaczenie grzechu.

Dalej prof. Laube wyjaśniał, że grzech jest niepojęty, ale im człowiek bardziej wierzy w Boga, tym lepiej rozumie grzech. Nie da się tłumaczyć grzechu naturalistycznie. Wyjaśniając istotę ewangelickiego rozumienia grzechu, prelegent stwierdzil, że wszyscy są grzesznikami, niewolnikami grzechu (jestem grzesznikiem i nic na to nie poradzę). Grzech ma charakter strukturalny, ale też jest konsekwencją osobistych decyzji ludzi: u podstaw indywidualnych grzechów leży grzech pierworodny. Grzech to nie tylko synonim złego samopoczucia. Grzech jest niewiarą, ma odniesienie do Boga. W odróżnieniu od katolicyzmu ewangelizm podkreśla radykalizm grzechu: człowiek nie tyle grzeszy, ile jest grzesznikiem. Reformatorzy podkreślili ciężar grzechu: nie grzeszne czyny tworzą grzesznika, ale człowiek jest grzesznikiem i dlatego jego całe postępowanie jest grzeszne. Człowiek sam z siebie nie jest zdolny do czynienia dobra - to kamień węgielny reformacji. Człowiek nie jest panem swojej woli - Marcin Luter 
mówił o zniewolonej woli. Momentem wyznawania grzechu jest modlitwa. Ewangelicy podkreślają, że pojednanie z Bogiem dokonuje się przez Chrystusa, a katolicy, że pojednanie z Bogiem następuje przez Chrystusa w Kościele. Wspólne obu wyznaniom jest doświadczenie grzechu oraz rozróżnienie między grzechem i grzesznikiem. Szczególnie w kazaniu należy dawać jasno do zrozumienia, że potępienie grzechu nie oznacza potępienia grzesznika. Kwestie wiary mogą być rozumiane różnie, ale grzech jest doświadczeniem wspólnym - uświadamianym w sumieniu.

W dyskusji po wykładach prof. Heinz-Günther Schöttler dostrzegł w nich brak biblijnego fundamentu. Stwierdzil, że u podstaw biblijnego rozumienia grzechu (Rdz 2-3) tkwi zanik rozróżnienia między Stwórcą i stworzeniem. Ponadto podkreślano wielokrotnie, że grzech jest nie tyle tematem kazania, co raczej kontrapunktem przy omawianiu wybranego tematu, jakiegoś aspektu Dobrej Nowiny o zbawieniu. Zauważono też, że nie ma swego uzasadnienia teologicznego tłumaczenie katastrof naturalnych karą Bożą. Można takie tłumaczenia zrozumieć na płaszczyźnie historycznej jako pragnienie religijnego wyjaśnienia wydarzeń zachodzących w świecie i poszukiwanie religijnej odpowiedzi na pytania o przyczynę wydarzeń. Stwierdzono także, w oparciu o doświadczenia praktyków, że trudno się mówi kazania o grzechu. Jednocześnie jednak uznano, że nie ma lepszego momentu na mówienie o grzechu niż kazanie. Bo jeśli nie podczas kazania, to kiedy?

Uzupełnieniem usystematyzowanych konfesyjnych wykładów na temat grzechu był multimedialny referat prof. dra Hubertusa Luterbacha, który dotyczył grzechu z perspektywy kulturowo-historycznej. Poczynając od Starego Testamentu, prelegent omawiał różne spojrzenia na grzech. Uwzględniał rozróżnienie między kulturami nisko i wysoko rozwiniętymi. Podkreślał, że historia zna kultury, w których osobista odpowiedzialność człowieka i wolność jest ograniczona. Rozróżnił ponadto między czynem i intencją. W antyku etyczność czynu łączono z intencją. Z kolei fundamentem chrześcijańskiego ujęcia grzechu jest odniesienie do Boga. W oparciu o historyczne świadectwa prof. Luterbach mówił m.in., że był czas, w którym chrześcijanie wypowiadali prośbę o przebaczenie grzechów popełnionych ciałem i poszczególnymi zmysłami: słuchem, wzrokiem, dotykiem - zakładano, że Bóg nie pozwala, by jakikolwiek grzech przeszedł niezauważony. Mówił też o próbach, którym poddawano osoby oskarżone o popełnienie jakiegoś grzechu. Na przykład oskarżeni mieli przysięgać na szkatułkę z relikwiami albo przechodzić przez rozżarzone węgle. Oskarżano i skazywano na śmierć nawet zwierzęta, na przykład koguta, że jako świadek cudzołóstwa nie piał, albo psa, że wówczas nie szczekał.

Treść prezentowanych wykładów była pogłębiana i uzupełniana w małych grupach. Warto jeszcze dodać, że od wielu już lat w konferencjach organizowanych przez Arbeitsgemeinschaft für Homiletik biorą udział naukowcy z Polski. W konferencji monachijskiej uczestniczyli: ks. dr hab. Jan Twardy, ks. dr hab. Leszek Szewczyk, ks. dr hab. Henryk Sławiński oraz zajmująca się zagadnieniami z pogranicza teologii i językoznawstwa na gruncie polskim i niemieckim dr Elżbieta Kucharska. Następną konferencję zapowiedziano na wrzesień 2012 roku. Na miejsce obrad zaproponowano Wiedeń. 